\title{
Trajectories and magnitude of change in coral reef fish populations in Philippine marine reserves: a meta-analysis
}

\author{
R. J. Maliao $\cdot$ A. T. White $\cdot$ A. P. Maypa $\cdot$ \\ R. G. Turingan
}

Received: 15 December 2008/Accepted: 22 June 2009/Published online: 29 July 2009

(C) Springer-Verlag 2009

\begin{abstract}
Marine reserves are widely implemented worldwide to meet both conservation and fisheries management goals. This study examines the efficacy of Philippine marine reserves using meta-analysis by comparing variations in fish density (1) between reserves and adjacent fished reefs (spatial comparison), (2) within reserves before establishment relative to years following the establishment (temporal comparison), and (3) among reserves classified based on size, age, and enforcement capacity. A grand (total) mean of nineteen 22.3 ha coral reef reserves, protected for a mean duration of 8.2 years, were included in the meta-analyses. The overall density of fishes was higher in the reserves compared with the fished reefs and this difference was largely accounted for by exploited fishes. However, the overall density of fishes within the same reserves remained similar from the period before its establishment to several years following its establishment.
\end{abstract}

Communicated by Biology Editor Dr. Mark McCormick

R. J. Maliao $(\bowtie) \cdot$ R. G. Turingan

Department of Biological Sciences, Florida Institute

of Technology, 150 West University Blvd., Melbourne,

FL 32901-6975, USA

e-mail: rmaliao@fit.edu

\section{A. T. White}

Asia-Pacific Program, The Nature Conservancy, 923 Nu'uanu Avenue, Honolulu, HI 96817-1539, USA

A. T. White - A. P. Maypa

Coastal Conservation Education Foundation, Inc. (CCEF),

6200 Banilad, Cebu City, Philippines

\section{A. P. Maypa}

Zoology Department, University of Hawaii at Manoa,

2538 McCarthy Mall Edmondson 152, Honolulu,

HI 96822, USA
Only the density of nonexploited fishes increased significantly during years subsequent to the establishment of the reserves. Neither age nor size of reserves correlated with pattern of change in fish density following the establishment of the reserves; however, fish density was consistently higher in larger and older reserves relative to smaller and younger reserves in the spatial comparison. Furthermore, well-enforced reserves had higher density of exploited fishes relative to less-enforced reserves in both spatial and temporal comparisons. In general, the magnitude and trajectory of change in fish density following the establishment of Philippine marine reserves are influenced by (1) functional groups of fishes under consideration, (2) size and age of the reserve, and (3) level of enforcement of the regulatory mechanisms necessary to sustain a marine reserve.

Keywords Marine-protected area - Marine conservation · Coastal resource management · Fishing impact .

Overfishing $\cdot$ Ecological synthesis

\section{Introduction}

Global fisheries show signs of severe overexploitation, with global landings falling and several fish stocks experiencing a decline in size or are threatened with extinction (Roberts 1997; Pauly et al. 1998; Hutchings 2000). Marine reserves, a no fishing spatial management zone, are increasingly being used as fisheries management and conservation tool worldwide (Jennings 2001; Gell and Roberts 2003; Sale et al. 2005; Russ 2006; Christie and White 2007). Reserves are expected to protect and enhance the biotic structures within their borders, and then augment the adjacent fisheries through adult spillover and larval subsidy 
(Gell and Roberts 2003; Sale et al. 2005; Alcala et al. 2005; Russ 2006).

The recovery process of fish assemblages in reserves is complex and is influenced by a wide range of factors (Jennings 2001). These include the population size and species composition at the onset of protection and the life history characteristics of the fish species under consideration (Hutchings 2000; Jennings 2001), reserve age, size, spacing and habitat structural complexity (Botsford et al. 2003; Hastings and Botsford 2003; Russ et al. 2005; Claudet et al. 2008; Graham et al. 2008), and the magnitude of reduction of fishing mortality in the reserve as a function of enforcement (Russ 2006; Guidetti et al. 2008). Top-trophic level species (e.g., piscivores) are preferentially fished, and thus expected to respond positively with protection because of the elimination (or reduction) of fishing mortality in the reserves (Roberts 1997; Jennings 2001; Russ 2006). The pattern of response (i.e., reserve effects) of top-trophic level species is expected to correlate positively with the age, size, and enforcement capacity of the reserves under consideration (Hastings and Botsford 2003; Russ 2006; Guidetti et al. 2008; Claudet et al. 2008). On the contrary, nonexploited prey species in the reserves are expected to have minimal response or even respond negatively due to concomitant increase in predation pressure (Pinnegar et al. 2002; Graham et al. 2003).

The establishment of reserves has become a major conservation and fisheries management tool in the Philippines under the banner of community-based coastal resource management (White et al. 2000; Alcala and Russ 2006; Christie and White 2007; Maliao et al. 2009). Aside from more pressing economic reasons (White et al. 2000), fisheries conservation and management are particularly urgent in the Philippines because the country is considered as the epicenter of global marine biodiversity (Carpenter and Springer 2005). Currently, the Philippines has implemented $\sim 1,169$ marine reserves (Arceo et al. 2008). Thus, it is critical to evaluate the effectiveness of these reserves to allow continuous feedback of information necessary for adaptive management (Pomeroy et al. 2005; Maliao et al. 2009).

Meta-analysis, commonly used in the medical sciences to synthesize results from disparate studies (Fazey et al. 2004), has recently received wide application in summarizing results of marine reserves across multiple spatial and temporal scales (e.g., Mosquera et al. 2000; Côté et al. 2001; Halpern and Warner 2002; Halpern 2003; Guidetti and Sala 2007; Claudet et al. 2008; Maliao et al. 2009). Meta-analysis provides a rigorous statistical framework for the synthesis of results from disparate studies that may have used different designs, sample sizes, or taxa to test similar questions (Hedges and Olkin 1985; FernandezDuque 1997). However, the majority of previous meta-analytical studies evaluating the efficacy of reserves are based on the comparative analyses between reserves and fished reefs. Conclusions about the efficacy of reserves based on such spatial comparisons have to be interpreted with caution because of patterns that may be considered as artifacts of the criteria for selecting coral reefs that are designated as reserves (Edgar et al. 2004; Willis et al. 2003a; Russ 2006). The skepticism associated with the conclusions about the efficacy of reserves drawn from spatial comparisons may be ameliorated by examining the performance of the same set of reserves over time (e.g., Before-After and Control-Impact [BACI] design; Underwood 1994; Edgar et al. 2004; Russ et al. 2005; Russ 2006).

This study examines the efficacy of Philippine reserves using meta-analysis by comparing variations in fish density (1) between reserves and adjacent fished reefs (spatial comparison), (2) within reserves before establishment relative to years following establishment (temporal comparison), and (3) among reserves classified based on size, age, and enforcement capacity. It is hypothesized that fish density, particularly those species that are exploited by fishing (1) is higher in reserves than in adjacent fished reefs, (2) increases in reserves following years of protection, and (3) is higher in larger, older, and well-enforced reserves. This study is one of the more comprehensive studies of marine reserves to date because it simultaneously examines both spatial and temporal effects of reserve protection, as well as the effects of reserve size, age, and enforcement.

\section{Methodology}

\section{Data screening}

Studies that examined fish assemblages in the Philippine marine reserves were rigorously searched from both the gray (research reports of different research institutions in the Philippines) and scientific literature (using Aquatic Sciences and Fisheries Abstracts and Biological Abstracts). Studies were selected based on the following criteria: (1) enforcement capacity of the reserves is at least a level 2 based on the management rating system implemented by the Coastal Conservation and Education Foundation, Inc., (CCEF) and its partners in the Philippines (White et al. 2004; see Table 1 for the details of this criterion); (2) fish density values were simultaneously collected from coral reef reserves and adjacent fished reefs, and the same reserve had been monitored for fish density before and after its establishment, in order to conform with the BACI design (Underwood 1994; see Table 1 for the details of the sampling methodology); and (3) the study reported the 


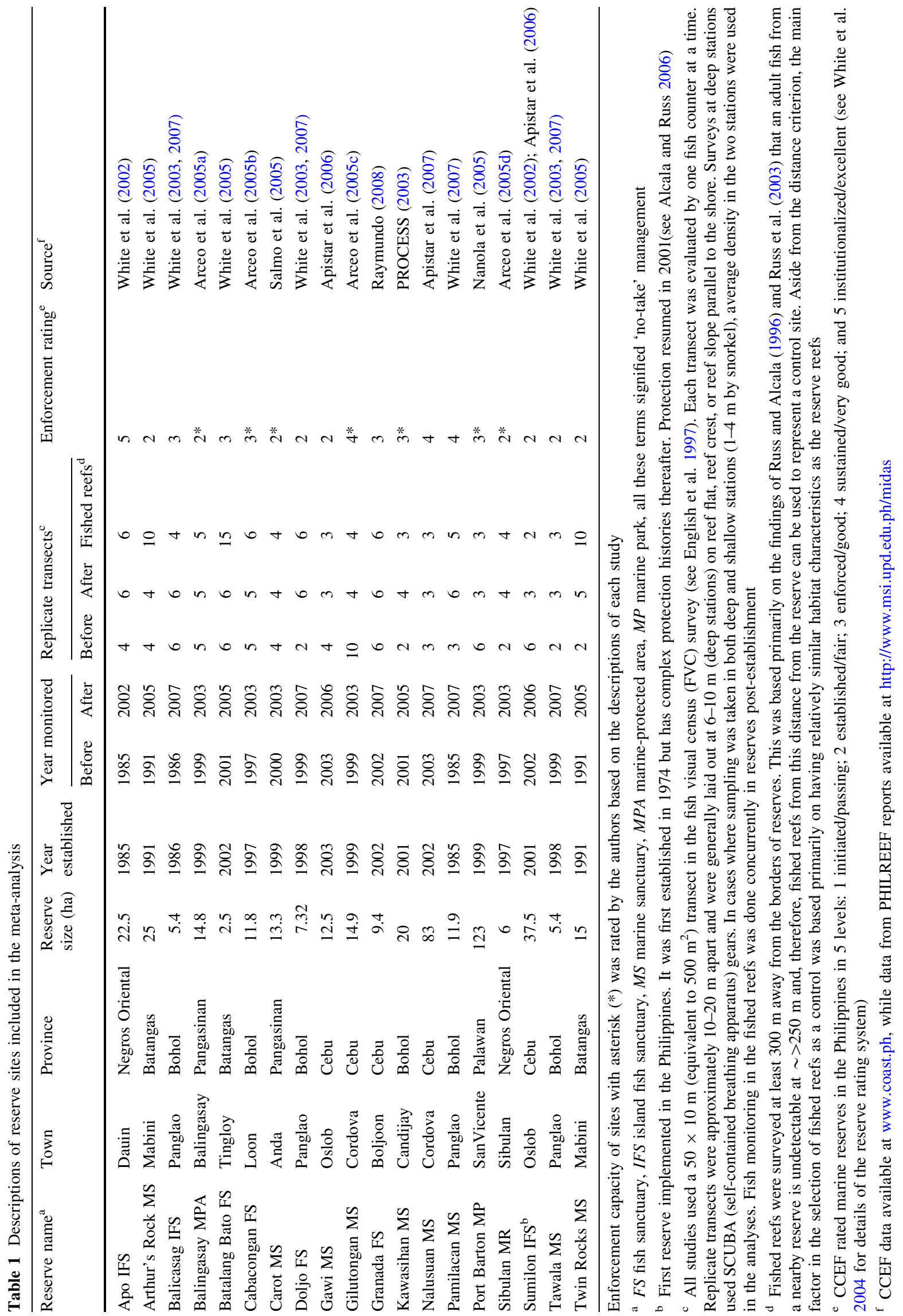


number of replicate transects surveyed, which was necessary for weighting of density estimates by sample sizes (Hedges and Olkin 1985). Fish density was used as the metric of reserve effect because it is the common variate reported in the studies included in the meta-analyses.

Based on the aforementioned criteria, a total of 16 studies covering 19 coral reef reserves in 13 municipalities in six Philippine provinces were selected (Fig. 1; Table 1). These reserves ranged in size from 2.5 to 83 ha (mean: 22.3) and were protected from 3 to 22 years (mean: 8.2).
Meta-analysis

For temporal comparisons, fish density in the reserves before and after their establishment served as the control and experimental values, respectively. In reserves where multiple year data on fish density values were available, the fish density estimated around reserve establishment was used as the control and the latest fish density was used as the experimental values, respectively, in order to avoid analytical problems associated with autocorrelation. For
Fig. 1 Map of the study sites. Refer to Table 1 for the abbreviations and site descriptions

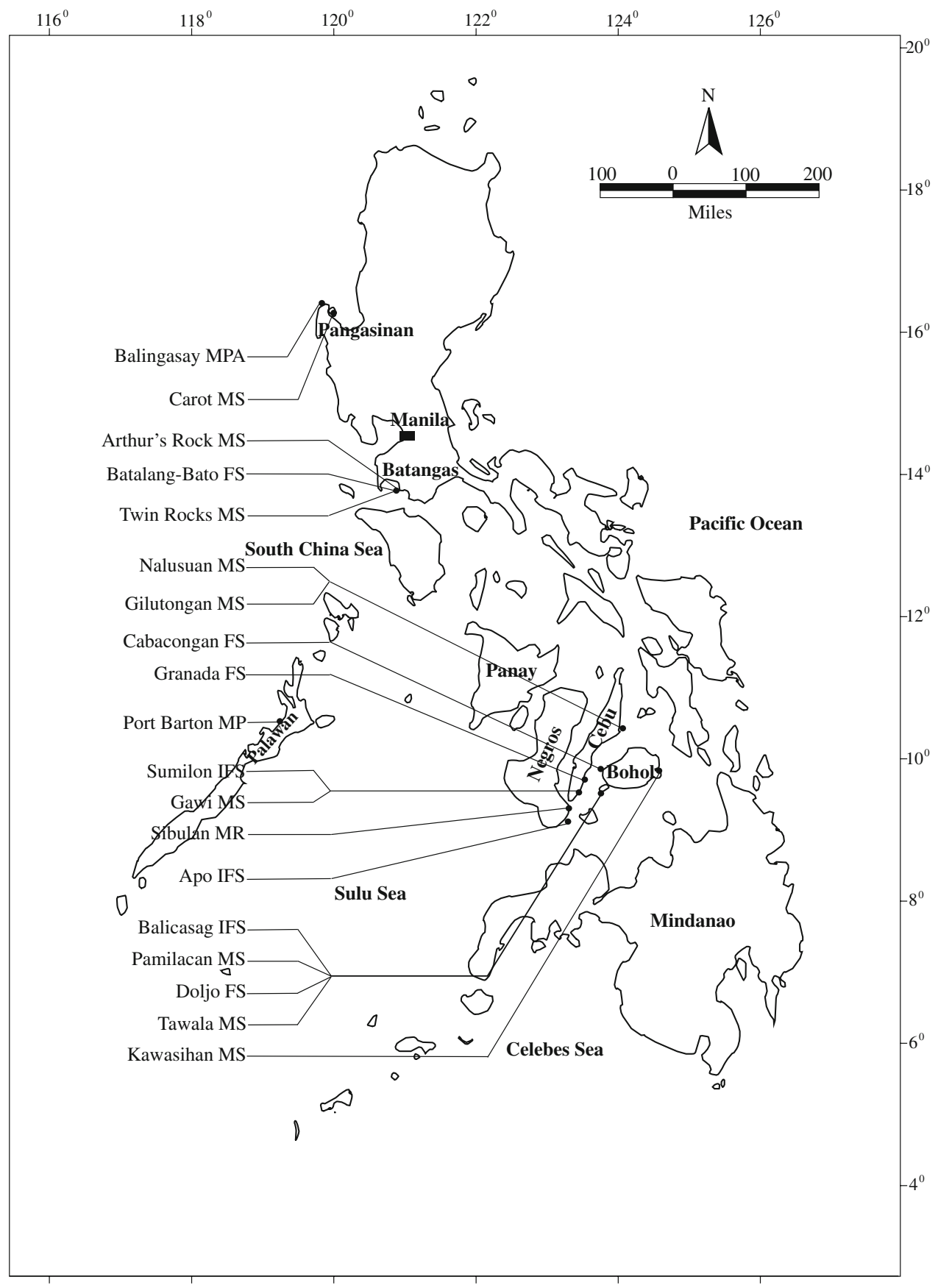


Table 2 Fish families and their trophic and exploitation classifications

\begin{tabular}{lll}
\hline Family & $\begin{array}{l}\text { Exploitation } \\
\text { category }\end{array}$ & $\begin{array}{l}\text { Trophic } \\
\text { group }\end{array}$ \\
\hline Carangidae (jack) & Exploited & Piscivores \\
Lutjanidae (snapper) & Exploited & Piscivores \\
Serranidae (grouper) & Exploited & Piscivores \\
Scaridae (parrotfish) & Exploited & Herbivores \\
Siganidae (rabbitfish) & Exploited & Herbivores \\
Acanthuridae (surgeonfish) & Exploited & Omnivores \\
Pomacanthidae (angelfish) & Nonexploited & Omnivores \\
Pomacentridae (damselfish) & Nonexploited & Omnivores \\
Anthiinae (fairy basslet) & Nonexploited & Planktivores \\
Caesonidae (fusilier) & Exploited & Planktivores \\
Balistidae (triggerfish) & Nonexploited & Invertivores \\
Labridae (wrass) & Nonexploited & Invertivores \\
Lethrinidae (emperor) & Exploited & Invertivores \\
Mullidae (goatfish) & Exploited & Invertivores \\
Haemulidae (sweetlips) & Exploited & Invertivores \\
Nemipteridae (coral bream) & Exploited & Invertivores \\
Zanclidae (moorish idol) & Nonexploited & Invertivores \\
Chaetodontidae (butterfly fish) & Nonexploited & Corallivores \\
\hline
\end{tabular}

spatial comparisons, the latest fish density estimated for the reserves was used as the experimental value (i.e., experimental value in the temporal comparisons) and the fish density concurrently estimated for the adjacent fished reefs was used as the control value. Each pair of reserve and fished reef and pre- and post-reserve comparison was treated as an independent study.

The analyses were limited to 18 fish families known to occupy coral reefs (Table 2). These fishes were classified into two fish groups. First, fishes were classified into trophic guilds (Froese and Pauly 2008); this classification scheme was used as the functional units in the analyses. Fishing disproportionately exploit species in high trophic levels; thus, any difference in the density of each trophic guild between reserves and fished reefs, as well as among years may be viewed as evidence for reserve effects on the functional relationships among fishes. These six trophic guilds are planktivores, herbivores, omnivores, invertivores, corallivores, and piscivores (Table 2). Second, to further test the heterogeneity of fish responses to protection, fishes were further classified into either 'exploited' (if they were deliberately fished) or 'nonexploited'(if they were not deliberately fished; Table 2).

In the meta-analysis, the effect size refers to the magnitude of reserve effect (i.e., magnitude of change in fish density) (Fernandez-Duque 1997) and is measured as the natural logarithm of the response ratio $(\ln R R$; Hedges and Olkin 1985; Rosenberg et al. 2000). Since there were cases where density was reported as zero, 0.0001 was added to all density values to be able to calculate the $\ln R R$ (Molloy et al. 2007). The $\ln R R$ for each fish group was calculated as:

$\ln R R=\ln \left(\frac{X^{e}}{X^{c}}\right)$

where $X^{e}$ and $X^{c}$ are the mean experimental and control density values, respectively. The mean effect $(\overline{\overline{\ln R R}})$ of each fish group was calculated based on the individual $\ln R R$ values of that particular fish group across studies (i.e., sites). $\overline{\overline{\ln R R}}$ values were weighted with more weight given to studies with lower variance (i.e., more precise that is a function of sample size) (Rosenberg et al. 2000). Weight $\left(w_{i}\right)$ for each study was defined as the inverse of the variance $\left(v_{i}\right)$ of the mean density of that fish group $\left(w_{i}=\frac{1}{v_{i}}\right)$. Since most studies included in the analyses did not report $v_{i}$ values, $v_{i}$ was approximated based on sample sizes as (Hedges and Olkin 1985):

$v_{i}=\left[\frac{\left(N_{i}^{e}+N_{i}^{c}\right)}{N_{i}^{e} N_{i}^{c}}\right]+\left[\frac{\left(\ln R R_{i}\right)^{2}}{2\left(N_{i}^{e}+N_{i}^{c}\right)}\right]$

where $N_{i}^{e}$ and $N_{i}^{c}$ are the study sample sizes for the experimental and control, respectively. Finally, the weighted $\overline{\overline{\ln R R}}$ of each fish group was calculated as (Hedges and Olkin 1985):

$\overline{\overline{\ln R R}}=\frac{\sum_{i=1}^{n} w_{i} \ln R R_{i}}{\sum_{i=1}^{n} w_{i}}$

where $n$ is the number of studies. The confidence interval (CI) values of each $\overline{\overline{\ln R R}}$ were based on the $95 \%$ biascorrected confidence limits around the mean calculated by bootstrapping after 999 iterations (Rosenberg et al. 2000). Back-transformed values of $\overline{\overline{\ln R R}}$ and CI were reported. The $\overline{\overline{R R}}$ was considered significantly different from 0 when its CI did not overlap with 1 (Rosenberg et al. 2000). The heterogeneity of responses among fish groups across sites was determined using the total heterogeneity $\left(Q_{T}\right)$ statistic as (Hedges and Olkin 1985):

$Q_{T}=\sum_{i=1}^{n} w_{i}\left(\ln R R_{i}-\overline{\overline{\ln R R}}\right)^{2}$.

Categorical meta-analysis was conducted between fish groups to determine whether the intragroup responses were significantly different. To determine the correlates of reserve effects, reserves were categorized according to reserve age ( $\leq 5: \geq 6$ years), reserve size $(\leq 10: \geq 11$ ha), and enforcement capacity $(2: \geq 3)$ and conducted categorical meta-analyses using these categories. The significance of the difference between fish groups and between categories was determined using the statistic $Q_{b}$ as (Hedges and Olkin 1985): 
$Q_{b}=\sum_{j=1}^{n} \sum_{i=1}^{k_{j}} w_{i j}(\ln R R-\overline{\overline{\ln R R}})^{2}$

where $n$ is the number of categories, $k_{j}$ is the number of studies in the $j$ th group, and $w_{i j}$ is the weight for the $i$ th study in the $j$ th group.

The significance of $Q_{T}$ and $Q_{b}$ was tested against the $\chi^{2}$ distribution with $n-1$ degrees of freedom. The metaanalyses were conducted using the categorical fixed-effects model in MetaWin version 2.1 (Rosenberg et al. 2000).

\section{Results}

\section{Spatial comparison}

The overall density of fishes in reserves was 1.64 times higher than in fished reefs $(\overline{\overline{R R}}=1.64, \mathrm{CI}=1.30-2.07)$ and this pattern was homogenous among sites (Fig. 2a; Table 3). The higher density of fishes in reserves was largely accounted for by exploited fishes relative to nonexploited fishes $\left(Q_{b}=5.96, d f=1, P=0.01\right)$. Nevertheless, densities of both exploited $(\overline{\overline{R R}}=2.53, \mathrm{CI}=1.70-3.49)$ and nonexploited $(\overline{R R}=1.47, \mathrm{CI}=1.14-1.91)$ fishes were significantly higher in reserves than in fished reefs and this trend was consistent across sites. Responses to protection among trophic guilds were significantly different $\left(Q_{b}=12.23, d f=5, P=0.03\right)$. Densities of piscivores $(\overline{\overline{R R}}=2.13, \quad \mathrm{CI}=1.05-2.50)$, herbivores $\quad(\overline{\overline{R R}}=2.15$, $\mathrm{CI}=1.38-3.27)$, omnivores $(\overline{\overline{R R}}=1.39, \mathrm{CI}=1.08-1.80)$, and planktivores $(\overline{\overline{R R}}=1.92, \mathrm{CI}=1.30-2.93)$ were significantly higher in reserves. On the other hand, densities of corallivores $(\overline{R R}=1.17, \mathrm{CI}=0.87-1.54)$ and invertivores $(\overline{R R}=1.25, \mathrm{CI}=0.92-1.72)$ in reserves were not significantly different from those in fished reefs. Responses to protection of piscivores, planktivores, herbivores, and corallivores were significantly heterogeneous among sites while that of invertivores and omnivores were consistent (Table 3).

In general, the above pattern of reserve effects remained consistent across age or size of reserves; however, fish density was consistently higher in older and larger reserves (Fig. 3a-d). The only exception was that the density of corallivores in larger reserves was significantly higher $(\overline{\overline{R R}}=1.54, \mathrm{CI}=1.16-2.16)$ than that in smaller reserves $(\overline{\overline{R R}}=0.79, \mathrm{CI}=0.55-1.31)$. Similarly, density of fishes appeared consistently higher in well-enforced reserves (Fig. 3e-f; Table 3). In particular, density of exploited fishes in well-enforced reserves was significantly higher $(\overline{R R}=3.74, \mathrm{CI}=2.54-5.20)$ than that in less-enforced reserves $(\overline{\overline{R R}}=1.64, \mathrm{CI}=1.00-2.66)$. Density of herbivores was also significantly higher in well-enforced reserves $(\overline{\overline{R R}}=2.99, \mathrm{CI}=1.62-4.70)$ than that in lessenforced reserves $(\overline{\overline{R R}}=1.40, \mathrm{CI}=0.64-2.83)$.

\section{Temporal comparison}

The overall fish density in reserves slightly increased (but not statistically significant) following reserve establishment $(\overline{\overline{R R}}=1.19$, CI $=0.84-1.65 ;$ Fig. $2 \mathrm{~b})$, and this pattern

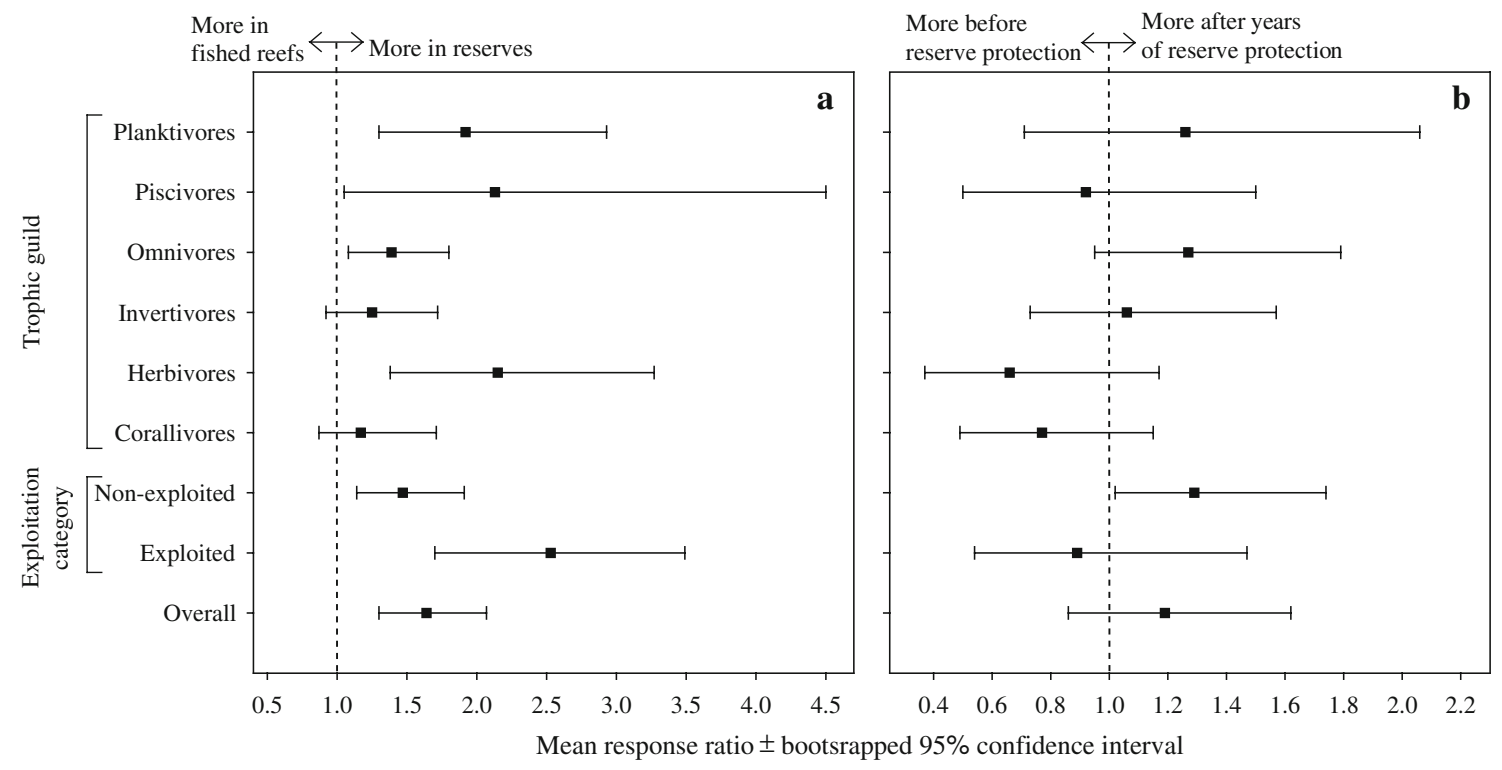

Fig. 2 Mean response ratio $(\overline{\overline{R R}})$ of fish groups indicating how fish density varies (a) between reserves and adjacent fished reefs (spatial comparison) and (b) within reserves from the time the reserve is established to the years following its establishment (temporal comparison). Statistics are given in Table 3 
Table 3 Summary statistics of meta-analyses for both spatial and temporal comparisons

\begin{tabular}{|c|c|c|c|c|c|c|c|c|c|c|c|c|c|c|c|c|}
\hline \multirow[t]{4}{*}{ Biotic group } & \multicolumn{8}{|c|}{ Spatial comparison } & \multicolumn{8}{|c|}{ Temporal comparison } \\
\hline & \multicolumn{2}{|c|}{$\begin{array}{l}\text { Overall meta- } \\
\text { analysis } \\
(\mathrm{DF}=18)\end{array}$} & \multicolumn{6}{|c|}{ Categorical meta-analysis } & \multirow{2}{*}{\multicolumn{2}{|c|}{$\begin{array}{l}\text { Overall meta- } \\
\text { analysis } \\
(\mathrm{DF}=18)\end{array}$}} & \multicolumn{6}{|c|}{ Categorical meta-analysis } \\
\hline & \multirow[b]{2}{*}{$Q_{T}$} & \multirow[b]{2}{*}{$P$} & \multicolumn{2}{|c|}{$\begin{array}{l}\text { Reserve age } \\
\text { in years (DF: } \\
\leq 5=8 \\
\geq 6=9 \text { ) }\end{array}$} & \multicolumn{2}{|c|}{$\begin{array}{l}\text { Reserve size } \\
\text { in ha (DF: } \\
\leq 10=6 \\
\geq 11=11)\end{array}$} & \multicolumn{2}{|c|}{$\begin{array}{l}\text { Enforcement } \\
\text { capacity (DF: } \\
\leq 2=8 \\
\geq 3=9 \text { ) }\end{array}$} & & & \multicolumn{2}{|c|}{$\begin{array}{l}\text { Reserve age } \\
\text { in years (DF: } \\
\leq 5=8 \\
\geq 6=9 \text { ) }\end{array}$} & \multicolumn{2}{|c|}{$\begin{array}{l}\text { Reserve size } \\
\text { in ha (DF: } \\
\leq 10=6 \\
\geq 11=11)\end{array}$} & \multicolumn{2}{|c|}{$\begin{array}{l}\text { Enforcement } \\
\text { capacity (DF: } \\
\leq 2=8 \\
\geq 3=9 \text { ) }\end{array}$} \\
\hline & & & $Q_{b}$ & $P$ & $Q_{b}$ & $P$ & $Q_{b}$ & $P$ & $Q_{t}$ & $P$ & $Q_{b}$ & $P$ & $Q_{b}$ & $P$ & $Q_{b}$ & $P$ \\
\hline Overall & 12.68 & 0.81 & 0.85 & 0.36 & 0.06 & 0.80 & 0.06 & 0.77 & 19.60 & 0.36 & 0.29 & 0.59 & 0.89 & 0.35 & 0.06 & 0.81 \\
\hline Exploited & 28.45 & 0.06 & 1.92 & 0.17 & 0.04 & 0.84 & 6.47 & 0.01 & 47.79 & 0.001 & 1.60 & 0.21 & 1.41 & 0.23 & 11.35 & 0.001 \\
\hline Nonexploited & 16.21 & 0.58 & 0.93 & 0.33 & 0.09 & 0.74 & 0.19 & 0.64 & 18.12 & 0.45 & 0.01 & 0.99 & 0.11 & 0.74 & 0.45 & 0.51 \\
\hline Corallivores & 32.86 & 0.02 & 0.01 & 0.98 & 4.43 & 0.02 & 0.18 & 0.68 & 50.30 & 0.01 & 2.99 & 0.29 & 1.60 & 0.38 & 0.01 & 0.95 \\
\hline Herbivores & 43.94 & 0.001 & 1.34 & 0.25 & 3.21 & 0.07 & 5.27 & 0.02 & 55.76 & 0.001 & 7.55 & 0.01 & 1.10 & 0.29 & 1.66 & 0.19 \\
\hline Invertivores & 18.44 & 0.43 & 2.45 & 0.12 & 1.86 & 0.21 & 0.34 & 0.56 & 33.27 & 0.02 & 0.67 & 0.41 & 0.46 & 0.50 & 0.21 & 0.64 \\
\hline Omnivores & 15.55 & 0.62 & 0.68 & 0.41 & 0.03 & 0.86 & 0.25 & 0.87 & 18.98 & 0.39 & 0.01 & 0.92 & 0.57 & 0.45 & 0.03 & 0.87 \\
\hline Piscivores & 126.7 & 0.001 & 0.03 & 0.85 & 0.07 & 0.78 & 0.65 & 0.42 & 93.99 & 0.001 & 1.03 & 0.31 & 1.56 & 0.21 & 0.01 & 0.90 \\
\hline Planktivores & $\mathbf{5 5 . 8 0}$ & 0.001 & 0.79 & 0.37 & 1.35 & 0.24 & 0.18 & 0.67 & 68.10 & 0.001 & 5.11 & 0.02 & 1.48 & 0.22 & 3.23 & 0.07 \\
\hline
\end{tabular}

The $Q_{T}$ and $Q_{b}$ statistics are measures of the difference of $\ln R R$ of each fish group between sites and the difference in $\overline{\overline{\ln R R}}$ between categories, respectively (see Meta-analysis section for details). The null hypotheses of these tests are that the $\ln R R$ of each fish group among sites and the $\overline{\overline{l n} R R}$ among categories are equal. $P$ values refer to the significance of both $Q_{T}$ and $Q_{b}$ under the $\chi^{2}$ distribution with $n$ (sites) - 1 degrees of freedom. Bolded text signified that the difference was statistically significant. A significant $Q_{T}$ implies that the variance among $\ln R R$ is greater than expected by sampling error, while a significant $Q_{b}$ implies that there are differences in $\overline{\ln R R}$ among categories

was homogenous among sites (see Table 3). Only nonexploited fishes significantly increased in density since the establishment of reserves $(\overline{\overline{R R}}=1.29, \mathrm{CI}=1.02-1.74)$, and this pattern was homogenous among sites. In contrast, density of exploited fishes, although not significant and heterogeneous among sites, declined by $11 \%$ following at least 8.2 years of protection $(\overline{\overline{R R}}=0.89, \mathrm{CI}=0.54-1.47)$. Nevertheless, responses among exploited and nonexploited fishes were not significant $\left(Q_{b}=2.51, d f=1, P=0.20\right)$. Responses among trophic guilds were significantly different $\left(Q_{b}=13.03, d f=5, P=0.02\right)$; but, on average, fish density values in reserves before their establishment were not significantly different from pre-reserve values. Densities of piscivores $(\overline{\overline{R R}}=0.92, \mathrm{CI}=0.46-1.87)$, herbivores $(\overline{\overline{R R}}=0.66, \quad \mathrm{CI}=0.37-1.17)$, and corallivores $(\overline{\overline{R R}}=$ $0.77, \mathrm{CI}=0.49-1.15)$ declined after years of protection. Invertivores $\quad(\overline{\overline{R R}}=1.06, \quad \mathrm{CI}=0.73-1.57), \quad$ omnivores $(\overline{\overline{R R}}=1.27, \mathrm{CI}=0.95-1.79)$, and planktivores $(\overline{\overline{R R}}=$ $1.26, \mathrm{CI}=0.71-2.06)$ slightly increased in density since the establishment of the reserves. Response of omnivores to protection was consistent among sites while the rest of the trophic groups were variable (Table 3 ).

Only herbivores and planktivores exhibited significant difference in their responses with reserve age. Density of herbivores in older reserves $(\overline{\overline{R R}}=0.38, \mathrm{CI}=0.19-0.76)$ was not only significantly lower than those in younger reserves $(\overline{\overline{R R}}=1.00, \mathrm{CI}=0.47-2.05$; Fig. 4a-b; Table 3), but also had significantly declined as well following several years of protection. Similarly, density of planktivores in older reserves $(\overline{\overline{R R}}=0.83, \mathrm{CI}=0.46-1.70)$ was significantly lower compared to those in younger reserves $(\overline{\overline{R R}}=1.87, \mathrm{CI}=0.66-3.78)$. On average, reserve effects appeared consistent regardless of reserve size (Fig. 4c-d). In terms of enforcement capacity, only exploited fishes exhibited significant difference between levels of reserve enforcement (Fig. 4e-f; Table 3). The density of exploited fishes in the less-enforced reserves $(\overline{\overline{R R}}=0.44$, $\mathrm{CI}=0.27-0.69)$ significantly declined after years of protection, and this value was significantly lower compared with well-enforced reserves $(\overline{R R}=1.44, \mathrm{CI}=0.69-2.83)$.

\section{Discussion}

This meta-analytical synthesis revealed many facets of the performance of Philippine marine reserves in enhancing fish density on coral reefs. In general, response of fish density to protection following reserve establishment is dependent on the (1) functional groups of fishes under consideration, (2) size and age of the reserve, and (3) enforcement capacity.

The higher overall density of fishes in the Philippine reserves relative to fished reefs $(\overline{\overline{R R}}=1.64)$ is consistent with the findings of previous meta-analyses at global 
Fig. 3 Mean response ratio $(\overline{R R})$ of fish groups indicating how fish density varies between reserves and adjacent fished reefs categorized according to a-b reserve age, $\mathbf{c}-\mathbf{d}$ reserve size, and $\mathbf{e}-\mathbf{f}$ enforcement capacity. The underlined fish groups had significant density between categories. Statistics are given in Table 3
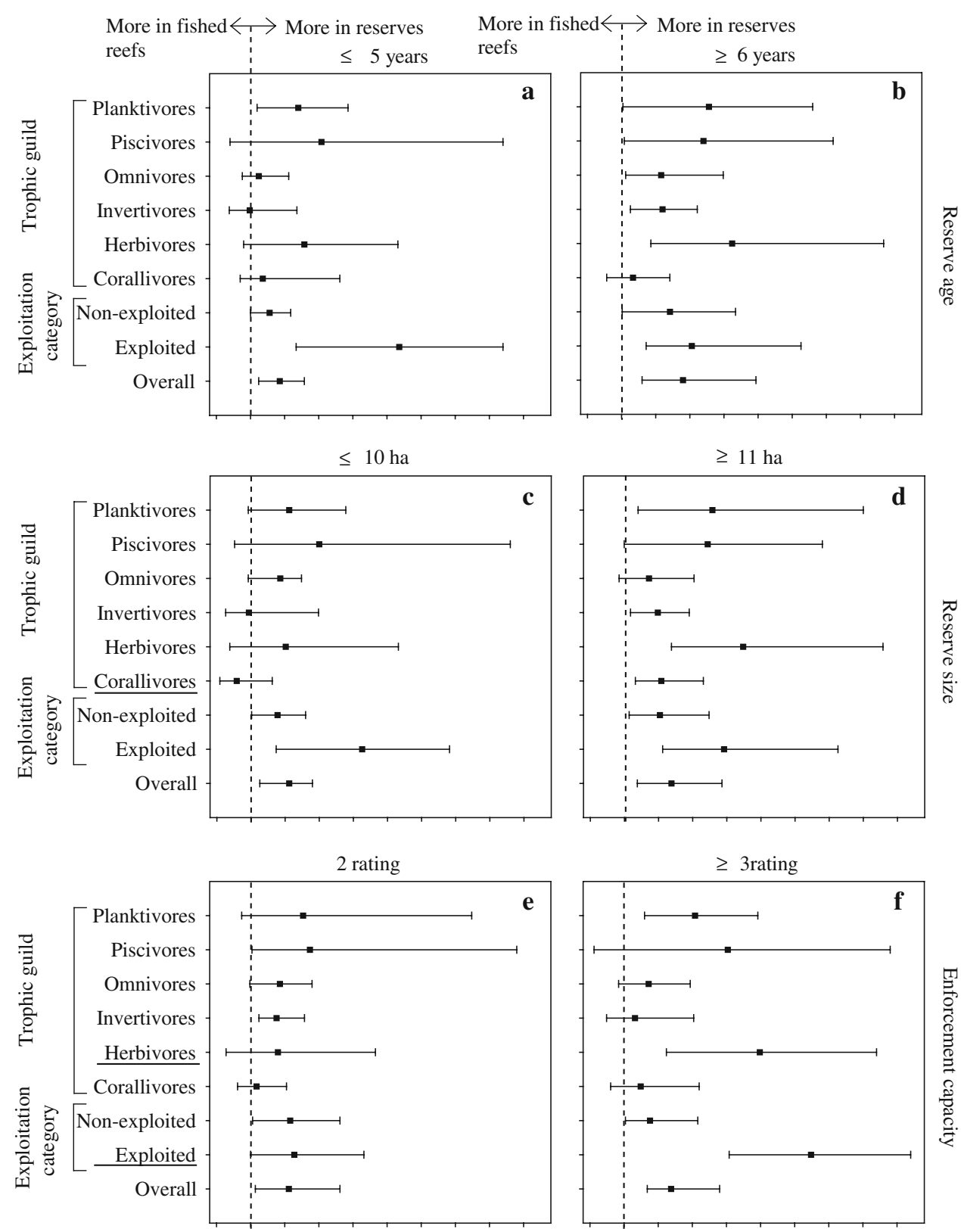

$\begin{array}{llllllllll}0.5 & 1.0 & 1.5 & 2.0 & 2.5 & 3.0 & 3.5 & 4.0 & 4.5 & 5.0\end{array}$

Mean response ratio \pm bootsrapped $95 \%$ confidence interval

$(\overline{\overline{R R}}=3.7$, Mosquera et al. 2000; $\overline{\overline{R R}}=1.9$, Halpern 2003) and regional levels (Mediterranean: $\overline{\overline{R R}}=1.2$, Guidetti and Sala 2007; Europe: $\overline{\overline{R R}}=2.5$, Claudet et al. 2008). Although there is a consensus that the overall fish density in reserves is significantly higher relative to fished sites, the magnitude of change following reserve establishment varies depending on the classification of fish under consideration (e.g., functional or taxonomic) and site-specific characteristics of the reserve (e.g., age, size, and habitat structure). An assessment of 81 reserves worldwide, Halpern (2003) revealed that fish density in $30 \%$ of these reserves did not differ from that of adjacent fished sites; in $7 \%$ of these reserves, fish density was actually lower compared with fished sites. Similarly, Micheli et al. (2004) found that $19 \%$ of the 376 species monitored in reserves worldwide have lower abundance relative to the fished sites. It has been hypothesized that the decline in numerical abundance of some fish species following the establishment of the reserves is caused by the cascading effects of subsequent changes in trophic interactions among species in the reserve (Pinnegar et al. 2002; Graham et al. 2003; Micheli et al. 2004).

In this study, it is noteworthy that the density of exploited fishes in the reserves was 2.53 times higher compared with the fished reefs, a conclusion that is consistent with the 
Fig. 4 Mean response ratio $(\overline{R R})$ of fish groups indicating how fish density varies within reserves from the time the reserve is established to the years following its establishment categorized according to $\mathbf{a}-\mathbf{b}$ reserve age, c-d reserve size, and $\mathbf{e}-\mathbf{f}$ enforcement capacity. The underlined fish groups had significant density between categories. Refer statistics given in Table 3
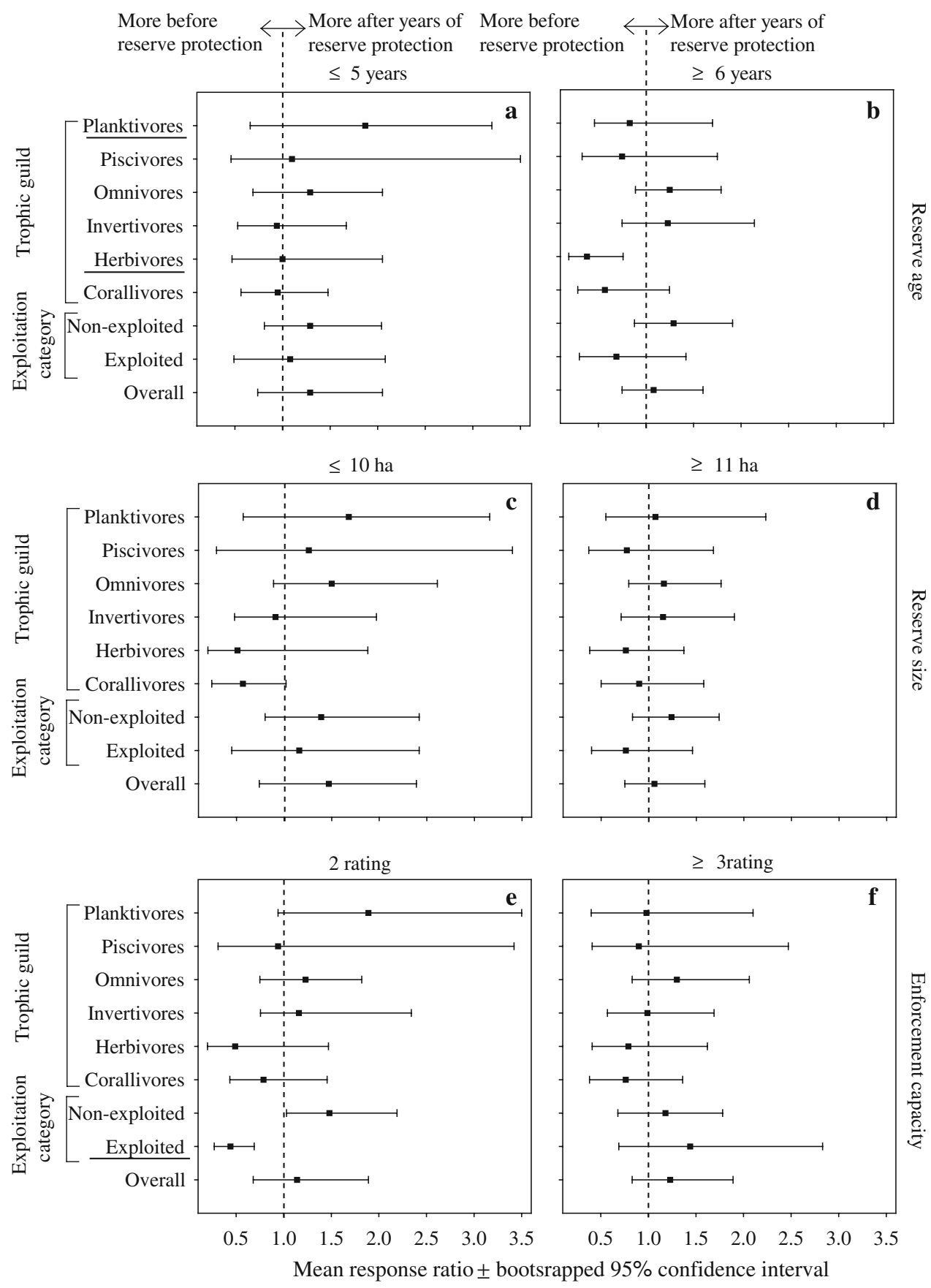

previous analyses of the Philippine reserves (e.g., Russ and Alcala 2003, 2004; Maliao et al. 2004; Russ et al. 2005; Alcala et al. 2005). This finding is also consistent with the results of previous assessment of reserves on coral reefs elsewhere (Friedlander et al. 2003; Graham et al. 2003; McClanahan et al. 2007; Harborne et al. 2008). Although at the outset it is tempting to attribute the higher density of exploited fishes in the reserves to the absence of fishing, it is conceivable that there are a multitude of factors that contribute to the observed disparity in fish density between reserves and the adjacent fished reefs.
Reserves worldwide may be designated in either resource-rich sites (i.e., higher values of biological measures) following the lobbying effort of conservationists and academicians (Edgar et al. 2004; Alcala and Russ 2006) or in resource-poor sites following the demands by local fishers to avoid losing traditionally prime fishing spots (Edgar et al. 2004; Francini-Filho and Moura 2008). Coraldwelling, small-bodied reef fishes (e.g., damselfish and fairy basslet; nonexploited fishes) are more reliant on the reef matrix for protection (Munday and Jones 1998); thus, their higher density in the reserves relative to the fished 
sites suggests that the Philippine reserves have more complex, resource-rich reef habitats compared with the fished reefs (see Christie et al. 2002; Walmsley and White 2003). If the current inter-reef disparity of habitat conditions reflects those at the time of designation of the reserve, then this may eventually translate into the disparate values for the metrics of performance (e.g., fish density) between reserves and fished reefs, in favor of the reserve. Over time, this difference in baseline fish density could further be magnified by the increased level of fishing in fished reefs as a consequence of the concentration of fishing effort in these locales after the designation of healthy, traditional fishing grounds as reserves (Alcala and Russ 2002; Christie et al. 2002). Fish density in the reserves may also be enhanced by fishes in the neighboring fished reefs immigrating into the reserves because of the presence of more food resources and better habitat quality (re: Ideal Free Distribution Theory of Fretwell and Lucas 1970), similar to the findings of Willis et al. (2003b) in the New Zealand reserves.

The use of BACI design type of analysis isolates the artifacts inherent in the spatial comparisons discussed earlier. However, temporal analyses of fish communities in reserves remain scarce, and results are variable among study sites (Roberts 1995; Wantiez et al. 1997; McClanahan 2000; Galal et al. 2002; Barrett et al. 2007; Kulbicki et al. 2007; also see Russ 2006 for a review). In the Philippines, Russ and Alcala $(2003,2004)$ reported a sustained increase in density of exploited fishes in Apo and Sumilon Reserves after decades of protection; in contrast, Christie et al. (2002) documented a decline in density of exploited fishes in Balicasag Reserve in Bohol. Results of the metaanalyses conducted in this study revealed that after an average of 8.2 years of protection, the reserves under consideration did not significantly enhance the density of fish populations in all trophic levels, except for nonexploited species. Nonetheless, the overall pattern of change in fish density during the period following the establishment of reserves in the Philippines suggests that on the average reserve age considered in this study, these reserves had been effective in maintaining the status quo of fish assemblages within them. This is similar to the previous reports of Christie et al. (2002) and Walmsley and White (2003) that in the central Philippines, reserves are more effective in enhancing or at least maintaining the biological conditions compared with the fished reefs. Thus, it is likely that the Philippine reserves play a critical role as a buffer against the adverse effects of localized overfishing.

In conducting both spatial and temporal meta-analyses synchronously on the same set of reserves in the Philippines, a contrasting pattern of change in fish density emerges, reflecting the constraints of each analytical approach. On one hand, the results of spatial comparisons share the same conclusion that fish density in the reserves are higher than that in fished reefs as those of Russ and Alcala $(2003,2004)$, Russ et al. (2005) and Alcala et al. (2005). On the other hand, the results of the temporal comparisons contradicted these findings. It is noteworthy that the works of Russ, Alcala, and colleagues are focused on two small, relatively isolated reserves at Sumilon and Apo Islands in the Philippines. In particular, the apparent success of the Apo Reserve has become an influential template for marine conservation in the country and is often cited as evidence for reserve success worldwide (Russ and Alcala 1996; Alcala and Russ 2006).

Exploited top-trophic level species are considered to be the best indicator of reserve performance (Russ and Alcala 2003, 2004; Russ 2006). When reserves were partitioned according to enforcement capacity in this study, density of exploited fishes was significantly higher in well-enforced reserves than those in less-enforced reserves, similar to the previous findings of Walmsley and White (2003) and Samoilys et al. (2007) in central Philippines and of Guidetti et al. (2008) in Italy. In fact, density of exploited fishes in less-enforced reserves significantly declined after years of protection, suggesting the prevalence of poaching. Poaching, generally cited as the major cause of the widespread failure of reserves in the Philippines (Christie et al. 2002; Walmsley and White 2003; Maliao et al. 2004, 2009; Russ 2006), as well as worldwide (Mora et al. 2006), can quickly negate the long-term and short-term positive effects of establishing the reserve. However, this result is highly variable across sites, which could be linked to the geographical location of the reserve. Mainland reserves are more accessible, thus are more vulnerable to poachers than remote island reserves (e.g., Apo and Sumilon Reserves), where resource stewardship is easier to establish and monitor (White et al. 2000; Maliao et al. 2009). Wellenforced reserves in this study are also on average older and larger compared with less-enforced reserves.

The magnitude of reserve effects have been shown to correlate positively with reserve age (Russ and Alcala 2003, 2004; Micheli et al. 2004; Guidetti and Sala 2007; Molloy et al. 2007; Claudet et al. 2008). However, this study, together with the studies of Mosquera et al. (2000), Côté et al. (2001) and Halpern and Warner (2002), demonstrated that the magnitude of reserve effect was independent of reserve age, although higher density was consistently found in older reserves in the spatial comparison. It is likely that the temporal pattern of response among fish groups was obscured by pooling the responses of fish species with different life histories (Russ et al. 2005). Differences in poaching intensity among reserves of different ages could also confound the pattern of reserve effects observed. In a recent meta-analysis of Philippine reserves based on fishers' perceptions, Maliao et al. (2009) demonstrated that poaching by 'roving bandits' is likely more prevalent in older reserves to maximize profits. Hence, the higher poaching 
intensity in older reserves relative to younger reserves could homogenize the pattern of reserve effects observed among reserves of different ages.

The structural complexity of coral reefs (e.g., percent live hard coral cover, slope and rugosity) is critical in the recovery of reef fish assemblages (Friedlander et al. 2003; Russ et al. 2005; Maliao et al. 2008; Graham et al. 2008). In this study, a comprehensive analysis of temporal and spatial changes in habitat structure could not be conducted because habitat data were not reported in most of the studies included in the meta-analyses. However, Philippine reserves are usually established on reefs that were formerly fishing grounds, and many suffered from the deleterious effects of overfishing and illegal fishing (e.g., blast fishing) before their establishment as reserves (White et al. 2000; Alcala and Russ 2002). The 1997/1998 El Niño Southern Oscillation (ENSO) further resulted in the massive decline of live coral cover in the Philippines (Arceo et al. 2001) and subsequent decline in reef fish populations in many parts of the world (Graham et al. 2008). A recent report of Marcus et al. (2007) states that based on 28 coral reef fishing grounds examined in central Philippines, the magnitude of coral-reef destruction is alarming; these authors reported that only $12 \%$ of the reefs are covered with live coral and the rest is covered with abiotic structures (69\%, e.g., coral rubble) and Sargassum (11\%). Although only a few fish species are heavily coral dependent, most reef fishes are reliant on the reef matrix for protection at some stage in their life cycle (Graham et al. 2008). Hence, the minimal overall impact of Philippine reserves in enhancing fish density is probably linked to persistent poor habitat condition and past climatic events. It is possible that older reserves in this study have more complex habitat compared with younger reserves, either because of reserve effects (Christie et al. 2002; Walmsley and White 2003), or simply because older reserves are initially designated in more complex reef habitat than those recently established reserves (Russ et al. 2005). The 1997/1998 ENSO possibly resulted to the homogenization of benthic structural complexity between older and younger reserves; hence, the relative magnitude of decline of fish assemblages, particularly for planktivores and herbivores, in older reserves was higher compared with younger reserves.

Finally, although any size of reserves can potentially enhance fish populations, empirical studies demonstrated that the magnitude of reserve effect correlates with reserve size (Edgar and Barrett 1999; Barrett et al. 2007; Claudet et al. 2008). This is consistent with theoretical studies suggesting that larger reserves are more effective in ensuring population persistence (Botsford et al. 2003; Hastings and Botsford 2003). However, this study, together with the meta-analyses of Côté et al. (2001), Halpern and Warner (2002), Halpern (2003), Micheli et al. (2004), and Guidetti and Sala (2007), indicated that the magnitude of reserve effect was independent of reserve size, although higher density was consistently found in larger reserves in the spatial comparison. A caveat here is that larger reserves are more difficult to monitor relative to smaller reserves, and thus more likely to be poached (Webb et al. 2004). In the spatial comparison, density of corallivores represented by chaetodontids was significantly lower in smaller reserves than in larger reserves. Since chaetodontids are generally associated with living corals (thus are often perceived as indicators of coral-reef health), their lower density in smaller reserves is perhaps reflective of the vulnerability of these small-size reserves to habitat disturbances relative to bigger reserves, thus decreasing the chance for healthy coral reefs to be sustained within these smaller reserves.

The strength of this meta-analytical study is the coupling of the results of conventional spatial comparisons with contemporary temporal approach in assessing the efficacy of marine reserves in the Philippines. However, the current analyses may suffer from some valid constraints. First, differences in habitat structure among reserves and fished reefs were not incorporated in the analyses. Second, fish density is considered a less robust metric of reserve effect compared with fish biomass. Fish density is susceptible to stochastic recruitment events and may remain stable or increase even if population biomass has declined due to size-selective poaching or size-dependent ontogenetic migrations. Finally, the density comparisons were based on a single, snapshot data set; thus, the analysis may have not accounted for stochastic sources of variation (see Kulbicki et al. 2007; Harborne et al. 2008). Despite these apparent weaknesses, the integration of spatial and temporal analyses on the same sets of data provides valuable, holistic information that increases our understanding of the utility and performance of marine reserves in the Philippines.

Acknowledgments R. J. Maliao and A. P. Maypa are supported by the Fulbright-Philippines Agriculture Scholarship Program. Key persons contributing to the Saving Philippine Reefs project annual coral reef monitoring expeditions of the CCEF are A. P. Maypa, B. Stockwell, S. Tesch, A. Meneses, E. White, and the volunteer divers that have supported the expeditions. Thanks to A. Uychiaoco, M. Vergara, and T. Dacles for providing copies of the reports from Reefs Through Time, a biennial report on the status of Philippine coral reefs. Comments of R. van Woesik, J. Lin, E. Webb, B. Polohan, J. Kerfoot, and M. Wittenrich on earlier drafts of this manuscript are gratefully acknowledged. We are thankful to the four anonymous reviewers for their valuable comments and recommendations to improve the quality of the manuscript.

\section{References}

Alcala AC, Russ GR (2002) Status of Philippine coral reef fisheries. Asian Fish Sci 15:177-192

Alcala AC, Russ GR (2006) No-take marine reserves and reef fisheries management in the Philippines: a new people power revolution. Ambio 35:245-254 
Alcala AC, Russ GR, Maypa AP, Calumpong HP (2005) A long-term, spatially replicated experimental test of the effect of marine reserves on local fish yields. Can J Fish Aquat Sci 62:98-108

Apistar DA, Diaz R, Lucas E, Raymundo D, Sabonsolin A, Tesch S (2006) Summary field report: reef monitoring survey in Gawi marine sanctuary and Sumilon island fish sanctuary, Oslob, Cebu, Philippines, 2006. The Coastal Conservation and Education Foundation Inc. (CCEF) and the Local Governance for Coastal Management Project (LGCMP), Cebu City, p 23

Apistar DA, Diaz R, Delizo D, Lucas E, Raymundo D, Sabonsolin A, Tesch S (2007) Summary field report: reef monitoring survey at Nalusuan island marine sanctuary, Cordova, Cebu, Philippines, 2007. CCEF and LGCMP, Cebu City, p 42

Arceo HO, Quibilan MC, Aliño PM, Lim G, Licuanan WY (2001) Coral bleaching in Philippine reefs: coincident evidences with mesoscale thermal anomalies. Bull Mar Sci 69:579-593

Arceo HO, Salmo SGIII, Aurellado EB, Alano HG (2005a) Balingasay marine protected area, Bolinao, Pangasinan. In: Miclat R, Sabater M, Quiblan MC, Tiquio GJ, Baria MV, Alonzo HK (eds) Reefs through time: 2004 biennial report on the status of Philippine coral reefs. Coral Reef Information Network of the Philippines (PHILREEFS) and the Marine Science Institute (MSI), University of the Philippines (UP), Diliman, Quezon City, pp 30-37

Arceo HO, Uychiaoco AJ, Nanola CL Jr (2005b) Cabacongan fish sanctuary, Loon, Bohol. In: Miclat R, Sabater M, Quiblan MC, Tiquio GJ, Baria MV, Alonzo HK (eds) Reefs through time: 2004 biennial report on the status of Philippine coral reefs. PHILREEFS and MSI, UP, Diliman, Quezon City, pp 139-144

Arceo HO, Uychiaoco AJ, Nanola CL Jr (2005c) Gilutongan marine sanctuary, Cordova, Cebu. In: Miclat R, Sabater M, Quiblan MC, Tiquio GJ, Baria MV, Alonzo HK (eds) Reefs through time: 2004 biennial report on the status of Philippine coral reefs. PHILREEFS and MSI, UP, Diliman, Quezon City, pp 79-84

Arceo HO, Uychiaoco AJ, Nanola CL Jr (2005d) Sibulan marine reserve, Sibulan, Negros oriental. In: Miclat R, Sabater M, Quiblan MC, Tiquio GJ, Baria MV, Alonzo HK (eds) Reefs through time: 2004 biennial report on the status of Philippine coral reefs. PHILREEFS and MSI, UP, Diliman, Quezon City, pp 105-109

Arceo HO, Alino PM, Gonzales RM (2008) Where are we now with marine protected areas? In: Alino PM, Geronimo RC, Mamauag SS, Gonzales RM (eds) Reefs through time 2008: initiating the state of the coasts reports. PHILREEFS, MPA Support Network, Marine Environment and Resources Foundation, Inc. (MERF) and UP-MSI, Diliman, Quezon City, pp 145-152

Barrett NS, Edgar GJ, Buxton CD, Haddon M (2007) Changes in fish assemblages following 10 years of protection in Tasmanian marine protected areas. J Exp Mar Biol Ecol 345:141-157

Botsford LW, Micheli F, Hastings A (2003) Principles for the design of marine reserves. Ecol Appl 13:S25-S31

Carpenter KE, Springer VG (2005) The center of the center of marine shore fish biodiversity: the Philippine islands. Environ Biol Fish 72:467-480

Christie P, White AT (2007) Best practices for improved governance of coral reef marine protected areas. Coral Reefs 26:1047-1056

Christie P, White A, Deguit E (2002) Starting point or solution? Community-based marine protected areas in the Philippines. J Environ Manag 66:441-454

Claudet J, Osenberg CW, Benedetti-Cecchi L, Domenici P, GarcíaCharton JA, Perez-Ruzafa A, Badalamenti F, Bayle-Sempere J, Brito A, Bulleri F (2008) Marine reserves: size and age do matter. Ecol Lett 11:481-489

Côté IM, Mosqueira I, Reynolds JD (2001) Effects of marine reserve characteristics on the protection of fish populations: a metaanalysis. J Fish Biol 59:178-189
Edgar GJ, Barrett NS (1999) Effects of the declaration of marine reserves on Tasmanian reef fishes, invertebrates and plants. J Exp Mar Biol Ecol 242:107-144

Edgar GJ, Bustamante RH, Fariña JM, Calvopiña M, Martíez C, Toral-Granda MV (2004) Bias in evaluating the effects of marine protected areas: the importance of baseline data for the Galapagos marine reserve. Environ Conserv 31:212-218

English S, Wilkinson C, Baker V (1997) Survey manual for tropical marine resources. Australian Institute of Marine Science, Townsville, Australia

Fazey I, Salisbury JG, Lindenmayer DB, Maindonald J, Douglas R (2004) Can methods applied in medicine be used to summarize and disseminate conservation research? Environ Conserv 31:190-198

Fernandez-Duque E (1997) Comparing and combining data across studies: alternatives to significance testing. Oikos 79:616-618

Francini-Filho RB, Moura RL (2008) Evidence for spillover of reef fishes from a no-take marine reserve: an evaluation using the before-after control-impact (BACI) approach. Fish Res 93: 346356

Fretwell SD, Lucas HL Jr (1970) On territorial behaviour and other factors influencing habitat distribution in birds. I. Theoretical development. Acta Biotheor 19:16-36

Friedlander AM, Brown EK, Jokiel PL, Smith WR, Rodgers KS (2003) Effects of habitat, wave exposure, and marine protected area status on coral reef fish assemblages in the Hawaiian archipelago. Coral Reefs 22:291-305

Froese R, Pauly D (eds) (2008) FishBase. World Wide Web electronic publication. www.fishbase.org, version 02/2008

Galal N, Ormond RFG, Hassan O (2002) Effect of a network of notake reserves in increasing catch per unit effort and stocks of exploited reef fish at Nabq, South Sinai, Egypt. Mar Freshw Res 53:199-206

Gell FR, Roberts CM (2003) Benefits beyond boundaries: the fishery effects of marine reserves. Trends Ecol Evol 18:448-455

Graham NAJ, Evans RD, Russ GR (2003) The effects of marine reserve protection on the trophic relationships of reef fishes on the Great Barrier Reef. Environ Conserv 30:200-208

Graham NAJ, McClanahan TR, MacNeil MA, Wilson SK, Polunin NVC, Jennings S, Chabanet P, Clark S, Spalding MD, Letourneur Y, Bigot L, Galzin R, Öhman M, Garpe KC, Edwards AJ, Sheppard CRC (2008) Climate warming, marine protected areas and the ocean-scale integrity of coral reef ecosystems. PLoS ONE 3(8):e3039

Guidetti P, Sala E (2007) Community-wide effects of marine reserves in the Mediterranean Sea. Mar Ecol Prog Ser 335:43-56

Guidetti P, Milazzo M, Bussotti S, Molinari A, Murenu M, Pais A, Spano N, Balzano R, Agardy T, Boero F, Carrada G, CattaneoVietti R, Cau A, Chemello R, Greco S, Manganaro A, Notarbartolo di Sciara G, Russo GF, Tunesi L (2008) Italian marine reserve effectiveness: does enforcement matter? Biol Conserv 141:699-709

Halpern BS (2003) The impact of marine reserves: do reserves work and does reserve size matter? Ecol Appl 13:S117-S137

Halpern BS, Warner RR (2002) Marine reserves have rapid and lasting effects. Ecol Lett 5:361-366

Harborne AR, Mumby PJ, Kappel CV, Dahlgren CP, Micheli F, Holmes KE, Sanchirico JN, Broad K, Elliott IA, Brumbaugh DR (2008) Reserve effects and natural variation in coral reef communities. J Appl Ecol 45:1010-1018

Hastings A, Botsford LW (2003) Comparing designs of marine reserves for fisheries and for biodiversity. Ecol Appl 13:65-70

Hedges LV, Olkin I (1985) Statistical methods for meta-analysis. Academic Press, San Diego

Hutchings JA (2000) Collapse and recovery of marine fishes. Nature 406:882-885 
Jennings S (2001) Patterns and prediction of population recovery in marine reserves. Rev Fish Biol Fish 10:209-231

Kulbicki M, Sarramégna S, Letourneur Y, Wantiez L, Galzin R, MouTham G, Chauvet C, Thollot P (2007) Opening of an MPA to fishing: natural variations in the structure of a coral reef fish assemblage obscure changes due to fishing. J Exp Mar Biol Ecol 353:145-163

Maliao RJ, Webb EL, Jensen KR (2004) A survey of stock of the donkey's ear abalone, Haliotis asinina L. in the Sagay marine reserve, Philippines: evaluating the effectiveness of marine protected area enforcement. Fish Res 66:343-353

Maliao RJ, Turingan RG, Lin J (2008) Phase-shift in coral reef communities in the Florida Keys National Marine Sanctuary (FKNMS), USA. Mar Biol 154:841-853

Maliao RJ, Pomeroy RS, Turingan RG (2009) Performance of community-based coastal resource management (CBCRM) programs in the Philippines: a meta-analysis. Mar Policy 33:818825

Marcus JE, Samoilys MA, Meeuwig JJ, Villongco ZAD, Vincent ACJ (2007) Benthic status of near-shore fishing grounds in the central Philippines and associated seahorse densities. Mar Pollut Bull 54:1483-1494

McClanahan TR (2000) Recovery of a coral reef keystone predator, Balistapus undulatus, in East African marine parks. Biol Conserv 94:191-198

McClanahan TR, Graham NAJ, Calnan JM, MacNeil MA (2007) Toward pristine biomass: reef fish recovery in coral reef marine protected areas in Kenya. Ecol Appl 17:1055-1067

Micheli F, Halpern BS, Botsford LW, Warner RR (2004) Trajectories and correlates of community change in no-take marine reserves. Ecol Appl 14:1709-1723

Molloy PP, Reynolds JD, Gage MJG, Mosqueira I, Côté IM (2007) Links between sex change and fish densities in marine protected areas. Biol Conserv 14:187-197

Mora C, Andrefouet S, Costello MJ, Kranenburg C, Rollo A, Veron J, Gaston KJ, Myers RA (2006) Coral reefs and the global network of marine protected areas. Science 312:1750-1751

Mosquera I, Côté IM, Jennings S, Reynolds JD (2000) Conservation benefits of marine reserves for fish populations. Anim Conserv 3:321-332

Munday PL, Jones GP (1998) The ecological implications of small body size among coral-reef fishes. Ocean Mar Biol Ann Rev 36:373-411

Nanola CL, Arceo HO, Uychiaoco AJ (2005) Port Barton marine park, San Vicente, Palawan. In: Miclat R, Sabater M, Quiblan MC, Tiquio GJ, Baria MV, Alonzo HK (eds) Reefs through time: 2004 biennial report on the status of Philippine coral reefs. PHILREEFS and MSI, UP, Diliman, Quezon City, pp 62-67

Pauly D, Christensen V, Dalsgaard J, Froese R, Torres F Jr (1998) Fishing down marine food webs. Science 279:860

Pinnegar JK, Polunin NVC, Francour P, Badalamenti F, Chemello R, Harmelin-Vivien ML, Hereu B, Milazzo M, Zabala M, D'Anna G (2002) Trophic cascades in benthic marine ecosystems: lessons for fisheries and protected-area management. Environ Conserv 27:179-200

Pomeroy RS, Watson LM, Parks JE, Cid GA (2005) How is your MPA doing? A methodology for evaluating the management effectiveness of marine protected areas. Ocean Coast Manage $48: 485-502$

PROCESS (2003) Kawasihan marine sanctuary fish assessment. Participatory, Research, Organization of Communities and Education Towards Struggle for Self-Reliance (PROCESS)Bohol Inc, Bohol

Raymundo DJC (2008) 2007 biophysical monitoring surveys in Southeast Cebu, Philippines. CCEF, Cebu City, p 14
Roberts CM (1995) Rapid build-up of fish biomass in a Caribbean marine reserve. Conserv Biol 9:815-826

Roberts CM (1997) Ecological advice for the global fisheries crisis. Trends Ecol Evol 12:35-38

Rosenberg MS, Adams DC, Gurevitch J (2000) MetaWin 2.0: statistical software for meta-analysis. Sinauer Associates, Massachusetts

Russ GR (2006) Yet another review of marine reserves as reef fishery management tools. In: Sale PF (ed) Coral reef fishes: dynamics and diversity in a complex ecosystem. Academic Press, San Diego, pp 421-443

Russ GR, Alcala AC (1996) Do marine reserves export adult fish biomass? Evidence from Apo Island, Central Philippines. Mar Ecol Prog Ser 132:1-9

Russ GR, Alcala AC (2003) Marine reserves: rates and patterns of recovery and decline of predatory fish, 1983-2000. Ecol Appl 13:1553-1565

Russ GR, Alcala AC (2004) Marine reserves: long-term protection is required for full recovery of predatory fish populations. Oecologia 138:622-627

Russ GR, Alcala AC, Maypa AP (2003) Spillover from marine reserves: the case of Naso vlamingii at Apo Island, the Philippines. Mar Ecol Prog Ser 264:15-20

Russ GR, Stockwell B, Alcala AC (2005) Inferring versus measuring rates of recovery in no-take marine reserves. Mar Ecol Prog Ser 292:1-12

Sale PF, Cowen RK, Danilowicz BS, Jones GP, Kritzer JP, Lindeman KC, Planes S, Polunin NVC, Russ GR, Sadovy YJ (2005) Critical science gaps impede use of no-take fishery reserves. Trends Ecol Evol 20:74-80

Salmo SG III, Arceo H, Pacifico KP, Aurellado EB, Alano HG (2005) Marine protected areas of Anda, Pangasinan. In: Miclat R, Sabater M, Quiblan MC, Tiquio GJ, Baria MV, Alonzo HK (eds) Reefs through time: 2004 biennial report on the status of Philippine coral reefs. PHILREEFS and MSI, UP, Diliman, Quezon City, pp 21-29

Samoilys MA, Martin-Smith KM, Giles BG, Cabrera B, Anticamara JA, Brunio EO, Vincent ACJ (2007) Effectiveness of five small Philippines' coral reef reserves for fish populations depends on site-specific factors, particularly enforcement history. Biol Conserv 136:584-601

Underwood AJ (1994) On beyond BACI: sampling designs that might reliably detect environmental disturbances. Ecol Appl 4:3-15

Walmsley SF, White AT (2003) Influence of social, management and enforcement factors on the long-term ecological effects of marine sanctuaries. Environ Conserv 30:388-407

Wantiez L, Thollot P, Kulbicki M (1997) Effects of marine reserves on coral reef fish communities from five islands in New Caledonia. Coral Reefs 16:215-224

Webb EL, Maliao RJ, Siar SV (2004) Using local user perceptions to evaluate outcomes of protected area management in the Sagay marine reserve, Philippines. Environ Conserv 31:138-148

White AT, Vogt HP, Arin T (2000) Philippine coral reefs under threat: the economic losses caused by reef destruction. Mar Pollut Bull 40:598-605

White AT, Christie P, Apurado J, Meneses A, Ovenden M, Tesch S, White E (2002) Summary field report: coral reef monitoring in Cebu, Negros and Siquijor, Philippines, March 23-31, 2002. CCEF and the Coastal Resource Management Project (CRMP), Cebu City, p 126

White AT, Stockwell B, Meneses A, Ovenden M, Tesch S, Apurado J, White E (2003) Summary field report: coral reef monitoring in Bohol and Siquijor, Philippines, April 11-30, 2003. CCEF and CRMP, Cebu City, p 126

White AT, Meneses AT, Ovenden MF (2004) Management rating system for marine protected areas: an important tool to improve 
management. In: DA-BFAR (Department of Agriculture-Bureau of Fisheries, Aquatic Resources) (ed) In turbulent seas: the status of Philippine marine fisheries. CRMP, Cebu City, pp 226-231

White AT, Maypa A, Tesch S, Stockwell B, Meneses A, White E, Mueller TJ (2005) Summary field report: coral reef monitoring expedition to Mabini and Tingloy, Batangas, Philippines, March 19-27, 2005. CCEF and the Fisheries Improved for Sustainable Harvest (FISH) Project, Cebu City, p 117

White AT, Meneses A, Tesch S, Maypa A, Stockwell B, White E, Martinez R (2007) Summary field report: coral reef monitoring in Bohol, Philippines, March 26-April 3, 2007. CCEF and FISH, Cebu City, p 111

Willis TJ, Millar RB, Babcock RC, Tolimieri N (2003a) Burdens of evidence and the benefits of marine reserves: putting Descartes before des horse? Environ Conserv 30:97-103

Willis TJ, Millar RB, Babcock RC (2003b) Protection of exploited fish in temperate regions: high density and biomass of snapper Pagrus auratus (Sparidae) in northern New Zealand marine reserves. J Appl Ecol 40:214-227 